\title{
Influence of the Vitamin D-binding Protein on the Serum Concentration of 1,25-Dihydroxyvitamin $\mathrm{D}_{3}$
}

\author{
SIGNIFICANCE OF THE FREE \\ 1,25-DIHYDROXYVITAMIN $\mathrm{D}_{3}$ CONCENTRATION
}

\author{
Roger Bouillon, Frans A. Van Assche, hugo Van Baelen, \\ Walter Heyns, and Pieter De MoOR, Laboratorium voor \\ Experimentele Geneeskunde and Department of Obstetrics, \\ Rega Instituut, Katholieke Universiteit Leuven, Leuven, Belgium
}

ABSTRACT The influence of the serum binding protein (DBP) for vitamin D and its metabolites on the concentration of its main ligands, 25-hydroxyvitamin $\mathrm{D}_{3}\left(25-\mathrm{OHD}_{3}\right)$ and 1,25-dihydroxyvitamin $\mathrm{D}_{3}(1,25-$ $[\mathrm{OH}]_{2} \mathrm{D}_{3}$ ) was studied. The concentration of both $1,25-$ $(\mathrm{OH})_{2} \mathrm{D}_{3}$ and $\mathrm{DBP}$ in normal female subjects $(45 \pm 14$ $\mathrm{ng} / \mathrm{liter}$ and $333 \pm 58 \mathrm{mg} / \mathrm{liter}$, mean $\pm \mathrm{SD}$, respectively; $n=58$ increased during the intake of estro-progestogens $(69 \pm 27 \mathrm{ng} /$ liter and $488 \pm 90 \mathrm{mg} /$ liter, respectively; $n=29$ ), whereas the $25-\mathrm{OHD}_{3}$ concentration remained unchanged. A positive correlation was found between the concentrations of $1,25-(\mathrm{OH})_{2} \mathrm{D}_{3}$ and DBP in these women.

At the end of pregnancy, the total concentrations of $1,25-(\mathrm{OH})_{2} \mathrm{D}_{3}(97 \pm 26 \mathrm{ng} / \mathrm{liter}, n=40)$ and DBP $(616$ $\pm 84 \mathrm{mg} /$ liter) are both significantly higher than in nonpregnant females and paired cord serum samples (48 $\pm 11 \mathrm{ng} / \mathrm{liter}$ and $266 \pm 41 \mathrm{mg} / \mathrm{liter}$, respectively). A marked seasonal variation of $25-\mathrm{OHD}_{3}$ was observed in pregnant females and their infants, whereas in the same samples the concentrations of both DBP and 1,25$(\mathrm{OH})_{2} \mathrm{D}_{3}$ remained constant throughout the year.

The free 1,25- $(\mathrm{OH})_{2} \mathrm{D}_{3}$ index, calculated as the molar ratio of this steroid and DBP, remains normal in women taking estro-progestogens, however, and this might explain their normal intestinal calcium absorption despite a high total $1,25-(\mathrm{OH})_{2} \mathrm{D}_{3}$ concentration. In pregnancy the free $1,25-(\mathrm{OH})_{2} \mathrm{D}_{3}$ index remains normal up to $35 \mathrm{wk}$ of gestation, but during the last weeks of

Part of this work was presented at the XVth European Symposium on Calcified Tissues 15-19 June 1980, Helsinki, Finland and appeared in abstract form. (1980. Calcif. Tissue Int. 31[Suppl.]: 32A.)

Received for publication 21 April 1980 and in revised form 6 October 1980. gestation, the free $1,25-(\mathrm{OH})_{2} \mathrm{D}_{3}$ index increases in both circulations. A highly significant correlation exists between the (total and free) $25-\mathrm{OHD}_{3}$ and 1,25- $(\mathrm{OH})_{2} \mathrm{D}_{3}$ concentrations in maternal and cord serum both at 35 and $40 \mathrm{wk}$ of gestation.

\section{INTRODUCTION}

The serum concentrations of thyroid hormones and cortisol depend on the concentration of their respective transport proteins, and only the concentration of free hormone is considered to be physiologically important $(1,2)$. The vitamin $D$ metabolites are also transported in the blood bound to a specific transport protein, called vitamin D-binding protein (DBP). ${ }^{1}$ It was previously shown that there is no correlation between the serum concentration of 25-hydroxyvitamin $\mathrm{D}_{3}\left(25-\mathrm{OHD}_{3}\right)$ and $\mathrm{DBP}$, indicating that the level of free $25-\mathrm{OHD}_{3}$ is not feedback regulated (3). The serum concentration of $1 \alpha, 25$-dihydroxyvitamin $\mathrm{D}_{3} \quad(1,25$ $[\mathrm{OH}]_{2} \mathrm{D}_{3}$ ) increases during human pregnancy (4-8), and this has been interpreted as a physiological adaptation to increase the intestinal calcium absorption in compensation for or even anticipation of the transfer of calcium to the fetus (8). The serum concentration of DBP, however, also increases during pregnancy or during the intake of estro-progestogens $(3,9)$, and the relative increase in both concentrations has not been compared. The concentration of DBP in maternal and cord sera has also an important influence on the concentration of $25-\mathrm{OHD}_{3}$ in both circulations (3), and

\footnotetext{
${ }^{1}$ Abbreviations used in this paper: DBP, serum binding protein for vitamin $\mathrm{D}$ and its hydroxylated metabolites; $25-\mathrm{OHD}_{3}, \quad 25$-hydroxyvitamin $\mathrm{D}_{3} ; 1,25-(\mathrm{OH})_{2} \mathrm{D}_{3}, \quad 1 \alpha, 25-$ dihydroxyvitamin $\mathrm{D}_{3}$.
} 
we now report a similar influence on the serum concentration of $1,25-(\mathrm{OH})_{2} \mathrm{D}_{3}$.

\section{METHODS}

Subjects. After informed consent, blood was taken from 58 healthy female blood donors without any medication (mean age $26 \mathrm{yr}$ ) and from 29 women (mean age $28 \mathrm{yr}$ ) taking estro-progestogens as oral contraceptive for at least one menstrual cycle. 50 women were also studied during pregnancy, and blood samples were obtained from 62 mothers and their infants at the time of delivery at the St. Rafael Hospital of Leuven, Belgium. Of these children, 40 were born at term $(40 \pm 1$ wk of gestation, mean \pm SD) with a birth weight of $3,469 \pm 308 \mathrm{~g} .22$ children were born prematurely $(35 \pm 1 \mathrm{wk}$ of gestation) with a mean birth weight of $2,299 \mathrm{~g}(\mathrm{SD}=433 \mathrm{~g})$. No vitamin D supplementation was given to the mothers, and the blood samples were randomly collected throughout the year. The average vitamin D intake in a pregnant Belgian population is $\sim 7 \mu \mathrm{g} / \mathrm{d}$.

Samples. Peripheral venous blood was taken from the adult females, kept at $4^{\circ} \mathrm{C}$, and centrifuged; the serum was then stored at $-20^{\circ} \mathrm{C}$. Mixed arterial and venous cord blood was treated similarly. In addition, separate blood from the cord artery and cord veins were collected in five cases. Paired samples from mothers and neonates were always run in the same assay to minimize interassay variation.

Methods. Serum $25-\mathrm{OHD}_{3}$ was measured by competitive protein-binding assay after extraction and Sephadex LH-20 chromatography as previously described (10). The between- assay variation was $10 \%$ for a sample containing $21 \mu \mathrm{g} /$ liter $(n=50)$. Serum $1,25-(\mathrm{OH})_{2} \mathrm{D}_{3}$ was measured by radioimmunoassay (11). For this assay, 2.5-5 ml of serum was extracted and purified sequentially on Sephadex LH-20 and high pressure liquid chromatography on a silicic acid column. The assay value was corrected by monitoring the overall recovery in each sample (mean $48 \pm 3 \%, n=50$ ) and the between-assay variation coefficient was $13 \%$ for a serum sample containing $42 \mathrm{ng} / \mathrm{liter}(n=24)$. The competitive protein-binding assay for $25-\mathrm{OHD}_{3}$ did not discriminate between $25-\mathrm{OHD}_{3}$ and $25-\mathrm{OHD}_{2}$, but our radioimmunoassay of $1,25-(\mathrm{OH})_{2} \mathrm{D}_{3}$ had only a low cross-reaction with 1,25 $(\mathrm{OH})_{2} \mathrm{D}_{2}$. Since, no vitamin $\mathrm{D}_{2}$ supplementation was used in our population, however, the values were expressed as the concentration of vitamin $D_{3}$ metabolites. Serum DBP was measured by single radial immunodiffusion with a betweenassay coefficient of variation of $2.5 \%$ (12). The concentrations of free $25-\mathrm{OHD}_{3}$ and $1,25-(\mathrm{OH})_{2} \mathrm{D}_{3}$ were calculated as the ratios between the molar concentrations of the vitamin $\mathrm{D}$ metabolites and DBP ("free 25- $\mathrm{OHD}_{2}$ and free $1,25-[\mathrm{OH}]_{2}$ $\mathrm{D}_{3}$ index"). As for other steroid and thyroid hormones, this simple molar ratio was probably a good indication of the real free (i.e., not bound to DBP) concentration. Indeed, the total binding sites for vitamin D metabolites (or serum DBP concentration) largely exceeded the concentration of all known possible ligands $(9,12,13)$, and the different genetic forms of DBP retained the same affinity for the main vitamin $D$ metabolites $(14,15)$. There was also no difference in affinity between maternal and neonatal DBP for 25- $\mathrm{OHD}_{3}$ (3) and 1,25-(OH $)_{2} \mathrm{D}_{3}$ (unpublished results). The absolute concentrations of free $25-\mathrm{OHD}_{3}$ and free $1,25-[\mathrm{OH}]_{2} \mathrm{D}_{3}$

TABLE I

\begin{tabular}{|c|c|c|c|c|c|c|c|c|}
\hline \multirow[b]{3}{*}{ Serum parameter } & \multirow{3}{*}{$\begin{array}{l}\text { Serum of } \\
\text { normal } \\
\text { females } \\
(58)\end{array}$} & \multicolumn{6}{|c|}{ Gestational duration } & \multirow{3}{*}{$\begin{array}{c}\text { Serum of } \\
\text { females } \\
\text { taking estro- } \\
\text { progestogens } \\
\text { (29) }\end{array}$} \\
\hline & & \multicolumn{4}{|c|}{ Maternal serum } & \multicolumn{2}{|c|}{ Cord serum } & \\
\hline & & $\begin{array}{l}18 \pm 4 \mathrm{wk} \\
(24)\end{array}$ & $\begin{array}{c}32 \pm 3 \mathrm{wk} \\
(26)\end{array}$ & $\begin{array}{l}35 \pm 1 \mathrm{wk} \\
(22)\end{array}$ & $\begin{array}{l}40 \pm 1 \mathrm{wk} \\
(40)\end{array}$ & $\begin{array}{c}35 \pm 1 \mathrm{wk} \\
(22)\end{array}$ & $\begin{array}{c}40 \pm 1 \mathrm{wk} \\
(40)\end{array}$ & \\
\hline $\begin{array}{l}1,25-(\mathrm{OH})_{2} \mathrm{D}_{3}, \\
\text { ng/liter }\end{array}$ & $45 \pm 14$ & $82 \pm 25^{*}$ & $88 \pm 34^{*}$ & $89 \pm 46^{*}$ & $97 \pm 26^{*}$ & $35 \pm 14 \ddagger$ & $48 \pm 11$ & $69 \pm 27^{*}$ \\
\hline $25-\mathrm{OHD}_{3}$, ng/liter & $14.0 \pm 6.4$ & $16.3 \pm 6.4^{*}$ & $13.8 \pm 4.2$ & $14.0 \pm 7.1$ & $13.5 \pm 5.0$ & $9.2 \pm 4.3 \ddagger$ & $8.3 \pm 3.8^{*}$ & $17.0 \pm 7 \S$ \\
\hline DBP, $m g / l i t e r$ & $333 \pm 58$ & $613 \pm 142 *$ & $683 \pm 82^{*}$ & $688 \pm 104^{*}$ & $616 \pm 84^{*}$ & $247 \pm 49^{*}$ & $266 \pm 41^{*}$ & $488 \pm 90^{*}$ \\
\hline $\begin{array}{l}\text { Free } 1,25-(\mathrm{OH})_{2} \mathrm{D}_{3} \\
\text { index }(\mathrm{molar} \\
\left.\text { ratio } \times 10^{5}\right)\end{array}$ & $1.8 \pm 0.4$ & $1.8 \pm 0.5$ & $1.7 \pm 0.6$ & $1.7 \pm 0.7$ & $2.2 \pm 0.6^{*}$ & $1.7 \pm 0.6$ & $2.5 \pm 0.6 \ddagger$ & $1.9 \pm 0.7$ \\
\hline $\begin{array}{l}\text { Free } 25-\mathrm{OHD}_{3} \\
\text { index }(\text { molar } \\
\left.\text { ratio } \times 10^{3}\right)\end{array}$ & $5.9 \pm 2.2$ & $3.7 \pm 1.4^{*}$ & $2.9 \pm 0.9^{*}$ & $2.9 \pm 1.8^{*}$ & $3.1 \pm 1.3^{*}$ & $4.9 \pm 2.3$ & $4.4 \pm 2.1 \ddagger$ & $5.1 \pm 1.9$ \\
\hline $\begin{array}{l}\text { Correlation } \\
\text { coefficient } \\
\text { between } \\
1,25-(\mathrm{OH})_{2} \mathrm{D}_{3} \\
\text { and } \mathrm{DBP}\end{array}$ & $0.60^{*}$ & $0.53 \ddagger$ & 0.24 & $0.62 \ddagger$ & $0.30^{\prime \prime}$ & $0.40^{\prime \prime}$ & 0.23 & $0.39^{\prime \prime}$ \\
\hline
\end{tabular}

Mean and standard deviation of the measured concentrations of $1,25-(\mathrm{OH})_{2} \mathrm{D}_{3}, 25-\mathrm{OHD}$, and $\mathrm{DBP}$, and the computed free $1,25-(\mathrm{OH})_{2} \mathrm{D}_{3}$ and $25-\mathrm{OHD}_{3}$ indexes. The correlation coefficients between $1,25-(\mathrm{OH})_{2} \mathrm{D}_{3}$ and DBP levels are indicated in the lower part of the table. No significant correlation was found between 25-OHD and DBP, $1,25-(\mathrm{OH})_{2} \mathrm{D}_{3}$ and $25-\mathrm{OHD} \mathrm{D}_{3}$, or between the free $1,25-(\mathrm{OH})_{2} \mathrm{D}_{3}$ and free $25-\mathrm{OHD}_{3}$ indexes in each group.

$* P<0.001$.

$\ddagger P<0.01$.

$\S$ In this group, a slight excess of samples taken during summer months increases the mean value of $25-\mathrm{OHD}$, but no significant difference was found when compared with a season-matched normal female group (taken from Fig. 1).

" $P<0.05$. 
could not be directly measured accurately because of their very low concentration and because of the problem of purity and adsorption of these steroids $(14,15)$. Using the law of mass action and the measured concentrations of (total) DBP, $25-\mathrm{OHD}_{3}$, and $1,25-(\mathrm{OH})_{2} \mathrm{D}_{3}$, an estimation of the free steroid concentration could be computed using a previously published formula (3). Using the affinity of DBP, measured at $4^{\circ} \mathrm{C}$ and $\mathrm{pH} 7.4$ (14-16), the approximate free concentrations of $25-\mathrm{OHD}_{3}$ and $1,25-(\mathrm{OH})_{2} \mathrm{D}_{3}$ in normal serum were 10 and $1 \mathrm{pM}$, respectively. This 10 -fold difference in free concentrations was markedly lower than the 320 -fold molar excess of total $25-\mathrm{OHD}_{3}$ over total $1,25-(\mathrm{OH})_{2} \mathrm{D}_{3}$ (Table I). Because the association constants at $37^{\circ} \mathrm{C}$ have not been thoroughly studied, we prefered to use the free index, especially for the comparison of this molar ratio in different situations.

Statistical analysis. A Wang 2200 computer (Wang Laboratories, Inc., Lowell, Mass.) was used for the calculation of correlation coefficients and paired and nonpaired Student's $t$ tests.

\section{RESULTS}

Serum DBP. The serum concentration of DBP increased during pregnancy and reached a maximum between 32 and 35 wk of gestation, followed by a small decrease at term. The cord serum concentration of DBP was lower than in nonpregnant females, without significant difference between levels at 35 and 40 wk of gestation (Table I). The concentration of DBP in maternal serum was thus more than twice as high as DBP in cord serum (Tables I and II). In women taking estro-progestogens, the DBP concentration was increased to a degree between the normal and pregnant levels (Table I). No seasonal variation of DBP was observed (Fig. 1).

25-Hydroxyvitamin $D_{3}$. The concentration of 25$\mathrm{OHD}_{3}$ in the serum of adults was not influenced by variations of serum DBP occurring during pregnancy or during intake of estro-progestogens (Table I). In- deed, no correlation was found between serum 25$\mathrm{OHD}_{3}$ and DBP in each subgroup of patients studied. A marked seasonal variation in serum $25-\mathrm{OHD}_{3}$ level was observed both in maternal and in cord serum (Fig. 1). A highly significant correlation was found between the concentration of $25-\mathrm{OHD}_{3}$ in maternal and cord serum, irrespective of season of delivery or gestational age (Table II). Compared with normal women, the free $25-\mathrm{OHD}_{3}$ index was significantly decreased during pregnancy and in women taking oral contraceptives, whereas the decrease in cord serum was less pronounced (Table I). The total concentration of $25-\mathrm{OHD}_{3}$ was significantly higher in maternal serum than in cord serum, but the inverse situation was found for free $25-\mathrm{OHD}_{3}$ (Table II).

1,25-Dihydroxyvitamin $D_{3}$. A significant positive correlation was found between the serum concentration of $1,25-(\mathrm{OH})_{2} \mathrm{D}_{3}$ and DBP in normal nonpregnant subjects with or without intake of estro-progestogens (Fig. 2). A similar positive correlation between both measurements was also found in most adult or neonatal subgroups (Table I). The concentration of 1,25$(\mathrm{OH})_{2} \mathrm{D}_{3}$ in maternal serum at each moment of gestation measured was significantly higher than in normal serum, whereas an intermediate concentration was found in the serum of patients taking estro-progestogens (Table I). The major increase was already present at $15 \mathrm{wk}$ of gestation, and the later increase was small (Fig. 3). In cord serum obtained at $35 \mathrm{wk}$ of gestation, the $1,25-(\mathrm{OH})_{2} \mathrm{D}_{3}$ concentration was lower than in the serum of nonpregnant females, but at $40 \mathrm{wk}$ there was no significant difference (Table I). The cord serum concentration of $1,25-(\mathrm{OH})_{2} \mathrm{D}_{3}$ was thus markedly lower than in the paired maternal serum, but the feto-maternal ratio was lower at 35 than at 40 weeks of gestation (Table II). No seasonal variation

TABLE II

\begin{tabular}{|c|c|c|c|c|c|}
\hline \multirow[b]{2}{*}{ Serum parameter } & \multicolumn{2}{|c|}{ Feto-maternal ratio* } & \multicolumn{3}{|c|}{$\begin{array}{c}\text { Feto-maternal correlation } \\
\text { coefficient }(r)\end{array}$} \\
\hline & $\begin{array}{l}35 \pm 1 \mathrm{wk} \\
(22)\end{array}$ & $\begin{array}{c}40 \pm 1 \text { wk } \\
(40)\end{array}$ & $\begin{array}{l}35 \pm 1 \mathrm{wk} \\
(22)\end{array}$ & $\begin{array}{c}40 \pm 1 \mathrm{wk} \\
(40)\end{array}$ & $\begin{array}{l}\text { All cases } \\
\quad(62)\end{array}$ \\
\hline DBP & $0.40 \ddagger$ & $0.43 \ddagger$ & $0.41 \S$ & 0.10 & $0.24 \S$ \\
\hline $25-\mathrm{OHD}_{3}$ & $0.66 \ddagger$ & $0.62 \S$ & $0.92 \ddagger$ & $0.76 \ddagger$ & $0.83 \ddagger$ \\
\hline $1,25-(\mathrm{OH})_{2} \mathrm{D}_{3}$ & $0.39 \ddagger$ & $0.49 \ddagger$ & $0.81 \ddagger$ & $0.50 \ddagger$ & $0.64 \ddagger$ \\
\hline Free $25-\mathrm{OHD}_{3}$ index & $1.7 \ddagger$ & $1.4 \ddagger$ & $0.96 \ddagger$ & $0.80 \ddagger$ & $0.86 \ddagger$ \\
\hline Free $1,25-(\mathrm{OH})_{2} \mathrm{D}_{3}$ index & 1.0 & $1.2^{\prime \prime}$ & $0.78 \ddagger$ & $0.58^{\prime \prime}$ & $0.66 \ddagger$ \\
\hline
\end{tabular}

Feto-maternal relationship of the measured or calculated concentrations of DBP, 25-OHD, and $1,25-(\mathrm{OH})_{2} \mathrm{D}_{3}$, and free $25-\mathrm{OHD}_{3}$ and free $1,25-(\mathrm{OH})_{2} \mathrm{D}_{3}$ indexes.

* The significance of the difference between the fetal and maternal concentrations was computed by means of a paired Student's $t$ test.

$f P<0.001$.

$\S P<0.05$.

" $P<0.01$. 


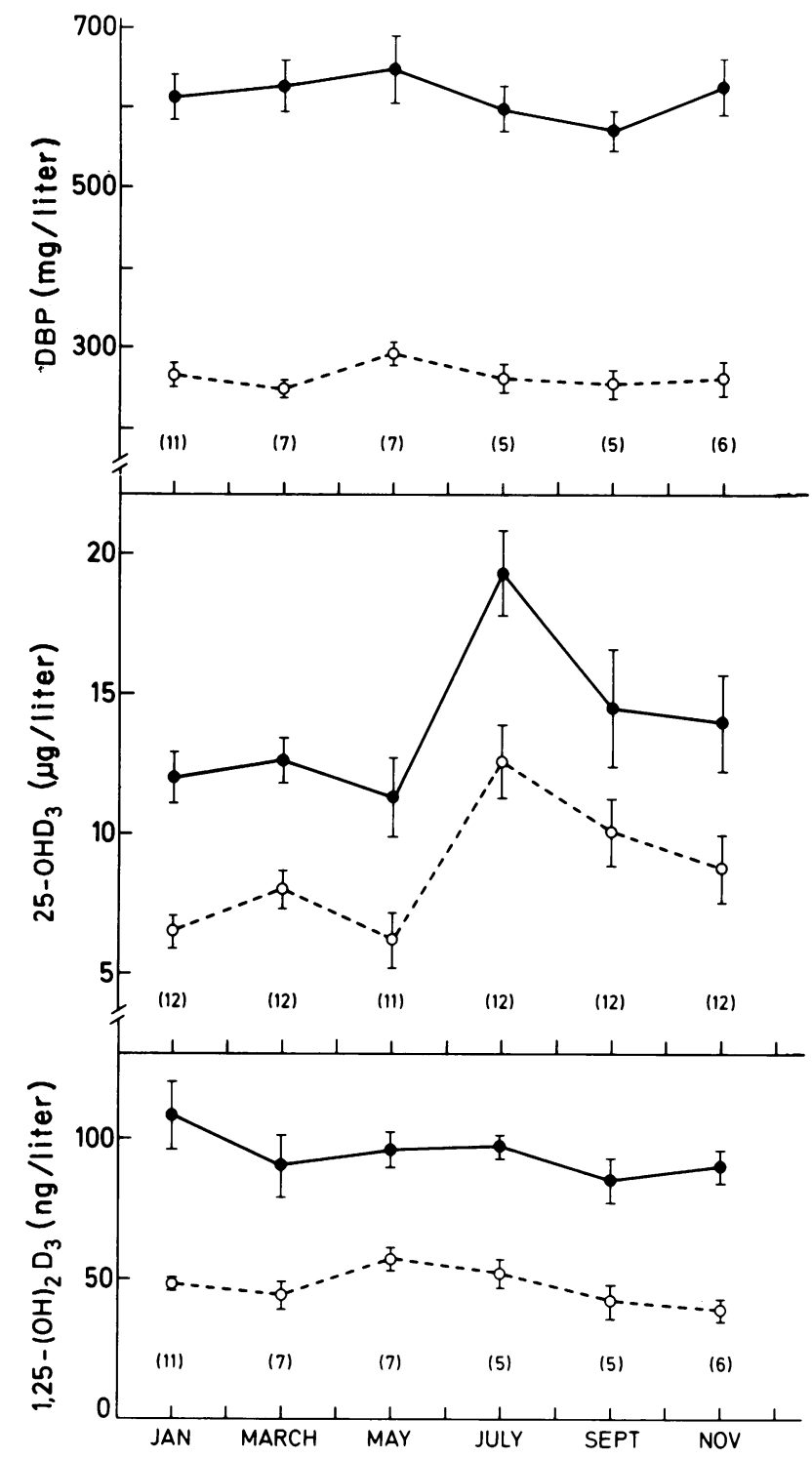

FIGURE 1 Seasonal variation of the concentrations of DBP, $25-\mathrm{OHD}_{3}$, and $1,25-(\mathrm{OH})_{2} \mathrm{D}_{3}$. These measurements were performed in 41 paired maternal and cord serum samples obtained from full-term deliveries ( $40 \pm 1 \mathrm{wk}$ of gestation). For $25-\mathrm{OHD}_{3}$, an additional series of 30 paired samples of full-term deliveries with a seasonal pattern identical to that of the first group was combined with the results of the previous group (middle panel). No significant seasonal difference was observed for DBP or $1,25-(\mathrm{OH})_{2} \mathrm{D}_{3}$, whereas a highly significant increase $(P<0.001)$ in serum $25 \mathrm{OHD}_{3}$ occurred during summer months, both in maternal and cord sera.

in the serum concentration of $1,25-(\mathrm{OH})_{2} \mathrm{D}_{3}$ was observed in either maternal or in cord serum (Fig. 1).

A positive correlation was found between the concentration of $1,25-(\mathrm{OH})_{2} \mathrm{D}_{3}$ in paired samples of maternal and cord sera, both at 35 and $40 \mathrm{wk}$ of gestation (Fig. 4). The free $1,25-(\mathrm{OH})_{2} \mathrm{D}_{3}$ index was not different from nonpregnant values at all stages of preg-

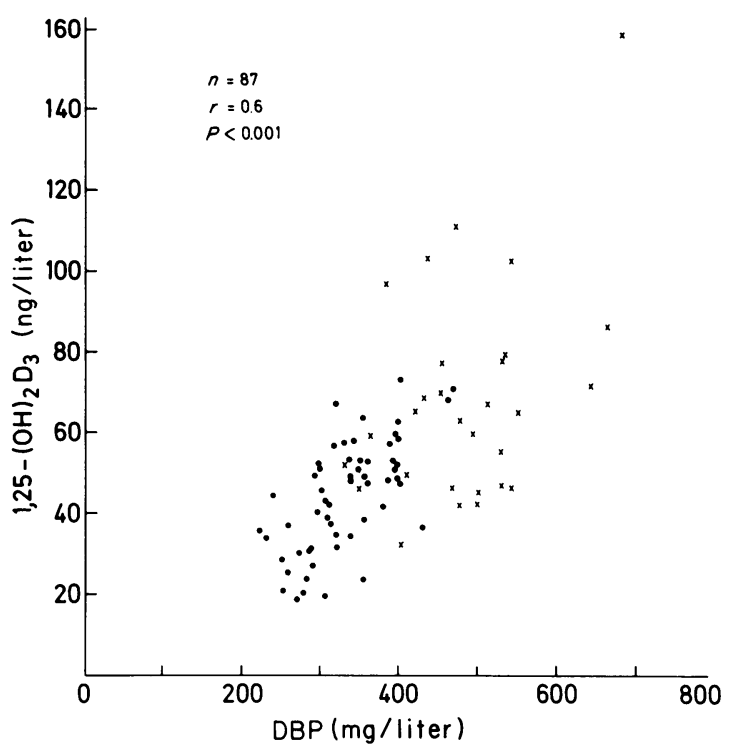

FIGURE 2 Relationship between the concentrations of 1,25$(\mathrm{OH})_{2} \mathrm{D}_{3}$ and $\mathrm{DBP}$ in 56 healthy blood donors $(O)$ and 29 women taking estro-progestogens $(x)$.

nancy, except at $40 \mathrm{wk}$ of gestation (Table I). Similarly, the free $1,25-(\mathrm{OH})_{2} \mathrm{D}_{3}$ index remained normal in women taking estro-progestogens. In cord serum obtained at $35 \mathrm{wk}$, the free $1,25-(\mathrm{OH})_{2} \mathrm{D}_{3}$ index was

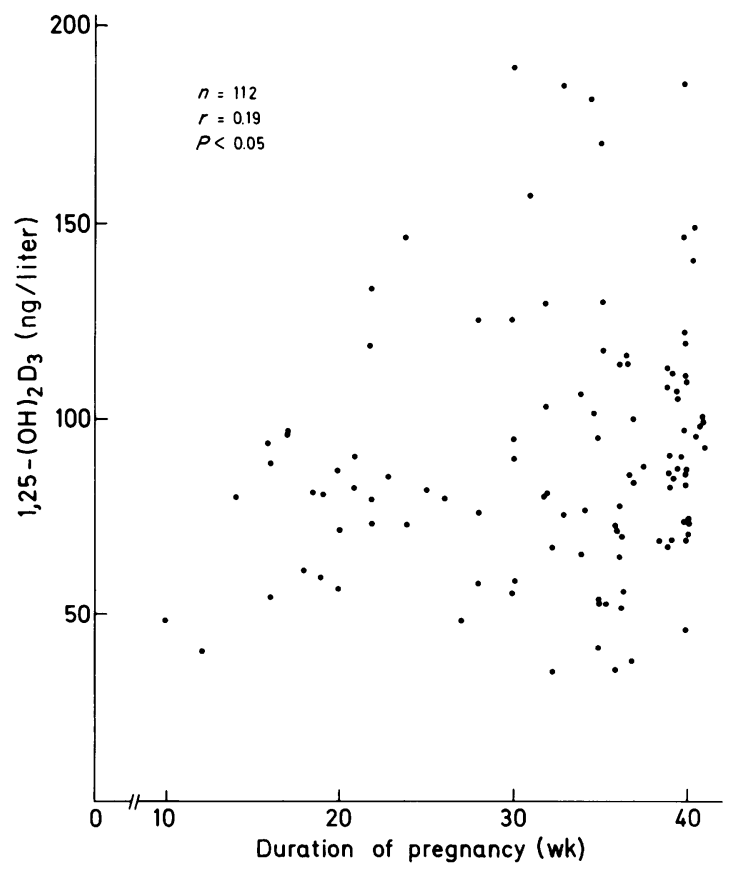

FIGURE 3 Serum concentrations of $1,25-(\mathrm{OH})_{2} \mathrm{D}_{3}$ plotted as a function of the duration of pregnancy. A wide variability in serum $1,25-(\mathrm{OH})_{2} \mathrm{D}_{3}$ is observed, with a significant tendency to increase progressively during gestation. 

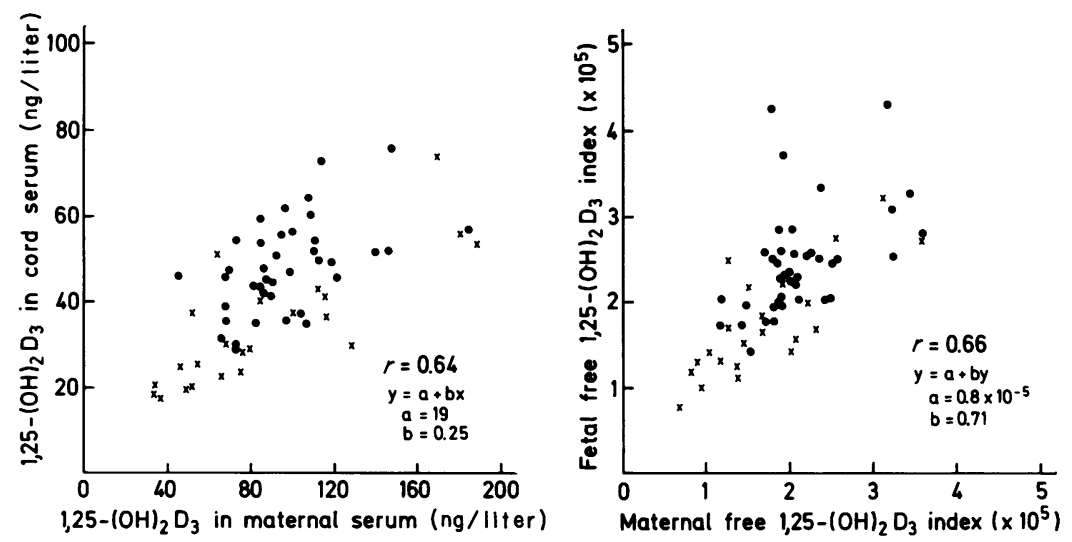

FIGURE 4 Relation between the serum concentrations of total (part A, left panel) and free (part B, right panel) $1,25-(\mathrm{OH})_{2} \mathrm{D}_{3}$ in paired maternal and cord sera samples as in Fig. 3 . 9 , Full-term deliveries; $\times$, premature deliveries.

identical to the maternal index at that stage of gestation. At 40 wk of gestation, however, the free 1,25$(\mathrm{OH})_{2} \mathrm{D}_{3}$ index was increased above the nonpregnant range both in maternal and cord sera, but the increase in the neonate exceeded the increase in maternal serum. At $40 \mathrm{wk}$ of gestation the free $1,25-(\mathrm{OH})_{2} \mathrm{D}_{3}$ index in cord serum was therefore higher $(P<0.002)$ than in the paired maternal samples.

The concentration of $1,25-(\mathrm{OH})_{2} \mathrm{D}_{3}$ measured in five samples of arterial cord serum $(40 \pm 9 \mathrm{ng} / \mathrm{liter}) \mathrm{did}$ not differ from the venous cord serum concentration $(41 \pm 12 \mathrm{ng} / \mathrm{liter})$ and was $44 \%$ of the paired maternal venous concentration. Similarly, no significant difference was found between the DBP level in arterial and venous cord sera.

No significant correlation was found between the serum concentrations of $25-\mathrm{OHD}_{3}$ and $1,25(\mathrm{OH})_{2} \mathrm{D}_{3}$ in all subgroups or in the combined pregnant and nonpregnant females.

\section{DISCUSSION}

The serum concentration of $1,25-(\mathrm{OH})_{2} \mathrm{D}_{3}$ is positively correlated with the DBP concentration in normal subjects and in women taking estro-progestogens (Fig. 2). This is also the case in cord serum and serum of pregnant females at most gestational ages tested (Table I). A similar positive relationship between other hormones and their respective transport protein has been documented (17-21).

In contrast, no correlation was found between the concentration of $25-\mathrm{OHD}_{3}$ and $\mathrm{DBP}$, either in normal subjects, pregnant females, or women taking oral contraceptives (Table I), confirming previous reports $(3,9,12,21)$. The positive correlation between 1,25 $(\mathrm{OH})_{2} \mathrm{D}_{3}$ and $\mathrm{DBP}$ indicates that the free steroid concentration is feedback regulated and thus physiologically important.
The concentrations of total $1,25-(\mathrm{OH})_{2} \mathrm{D}_{2}$ and DBP increase during the intake of estro-progestogens $(9,12)$ or estrogens alone $(22)$, whereas the $25-\mathrm{OHD}_{3}$ level remains unchanged (Table I). The free $25-\mathrm{OHD}_{3}$ concentration therefore decreases, whereas the free 1,25$(\mathrm{OH})_{2} \mathrm{D}_{3}$ level remains unchanged (Table I). Since it is well documented that the intestinal calcium absorption (25-28) does not change during the intake of estrogens, even when given in huge amounts to produce pseudopregnancy (29), and since bone resorption even seems to decrease (30-31), we assume that the free rather than the total concentration of $1,25-(\mathrm{OH})_{2} \mathrm{D}_{3}$ corresponds to its physiological effects on target cells. Indeed, in other situations with comparable increased concentrations of $1,25-(\mathrm{OH})_{2} \mathrm{D}_{3}$ not associated with increases in $\operatorname{DBP}(9,13)$, an important hyperabsorption of calcium is found (32-35). Administration of estrogens to osteoporotic women also increased the serum concentration of $1,25-(\mathrm{OH})_{2} \mathrm{D}_{3}$. Their free $1,25-(\mathrm{OH})_{2} \mathrm{D}_{3}$ concentration and their intestinal calcium absorption, however, both remained unchanged, indicating that the biological response of the target organ corresponds to the free rather than the total hormone concentration (36). If the increase in serum $1,25-(\mathrm{OH})_{2} \mathrm{D}_{3}$ is only secondary to the increase in serum DBP, it becomes clear why the stimulatory effect of estrogens on 1,25$(\mathrm{OH})_{2} \mathrm{D}_{3}$ production in vivo $(37,38)$ cannot be observed in cultures of isolated kidney cells $(39,40)$.

The serum concentration of $25-\mathrm{OHD}_{3}$ in pregnant females does not differ from normal subjects (Table I), whereas their serum DBP increases. This results in a decreased concentration of free $25-\mathrm{OHD}_{3}$. The concentration of $1,25-(\mathrm{OH})_{2} \mathrm{D}_{3}$ increases during pregnancy (Fig. 3), confirming previous data (4-8). The free $1,25-(\mathrm{OH})_{2} \mathrm{D}_{3}$ index, however, remains normal up to 35 wk of gestation. This means that the increase in free $1,25-(\mathrm{OH})_{2} \mathrm{D}_{3}$ in pregnancy is initially only an adaptation to the increased production of DBP. In the last 
month of pregnancy, however, a real increase in free $1,25-(\mathrm{OH})_{2} \mathrm{D}_{3}$ occurs, and this coincides with the period of large calcium transfer from the mother to the fetus (41). Other data also favor this hypothesis, as the decrease in serum ionized calcium (42) and the increase in serum parathyroid hormone $(43,44)$ is also limited to the last period of pregnancy. Only scarce data on calcium absorption in human pregnancy are available. Using a single stable calcium isotope technique, an increased intestinal calcium absorption was already observed in early pregnancy (29), when the free 1,25 $(\mathrm{OH})_{2} \mathrm{D}_{3}$ level is still normal. If these data were confirmed, an alternative explanation could be found in an altered sensitivity of the target organs, as is known for other hormones and even for $1,25-(\mathrm{OH})_{2} \mathrm{D}_{3}$ receptors (45). Another study could not reveal, however, an increased calcium absorption in the first trimester of pregnancy (46).

The concentration of total $1,25(\mathrm{OH})_{2} \mathrm{D}_{3}$ in cord serum is lower than in maternal serum, as has also been observed by Steichen et al. (7). At 35 wk of gestation, the total and free $1,25(\mathrm{OH})_{2} \mathrm{D}_{3}$ concentrations in cord serum are not different from nonpregnant values. Between 35 and 40 wk of gestation, however, a significant increase in total and free $1,25(\mathrm{OH})_{2} \mathrm{D}_{3}$ occurs in parallel to their increase in maternal serum. A relatively high free or effective concentration of 1,25$(\mathrm{OH})_{2} \mathrm{D}_{3}$ is thus present in the phase of greatest fetal bone formation. This is in contrast with the recent interpretation that the low (total) fetal $1,25-(\mathrm{OH})_{2} \mathrm{D}_{3}$ levels reflect a lack of need for fetal intestinal calcium absorption (7). The fetus, however, can absorb ingested amniotic fluid, and the normal (47) and even the prematurely born infant can absorb dietary calcium rather efficiently (48). Moreover, Care et al. (49) recently demonstrated that fetal $1,25-(\mathrm{OH})_{2} \mathrm{D}_{3}$ is necessary to promote the maternal-to-fetal calcium flux across the placenta.

A positive correlation was found between the maternal and cord serum concentrations of either total or free $25-\mathrm{OHD}_{3}$ (Fig. 2). This confirms numerous previous reports $(3,50-53)$ and is in agreement with a placental transfer of $25-\mathrm{OHD}_{3}(54)$. A positive correlation was also found between the maternal and cord serum concentrations of either total or free 1,25$(\mathrm{OH})_{2} \mathrm{D}_{3}$ both in premature and mature deliveries (Fig. 4). Since DBP does not cross the placenta (55), and free hormones in general are believed to be more important for the placental transfer than the total hormone concentration (56), we must suspect either an active placental transfer to the fetus or an additional synthesis of these vitamin D metabolites in the fetal compartment. Several data, indeed, demonstrate a fetal or placental synthesis of $1,25-(\mathrm{OH})_{2} \mathrm{D}_{3}(57-60)$. In a recent study, Steichen et al. (7) could not document a positive correlation between maternal and cord serum concentrations of $1,25-(\mathrm{OH})_{2} \mathrm{D}_{3}$. A model of separate maternal and fetal compartments of $1,25-(\mathrm{OH})_{2} \mathrm{D}_{3}$ was therefore suggested. They used venous cord blood instead of mixed cord blood as in the current study (7), but this cannot be the reason for the discrepancy, because we could not detect any arteriovenous difference in either DBP or $1,25-(\mathrm{OH})_{2} \mathrm{D}_{3}$. Moreover, they did not find a positive correlation between the maternal and cord serum concentrations of $25-\mathrm{OHD}_{3}$ either, contrary to many previous studies $(3,50-53)$. The placenta is generally considered permeable to the transfer of steroid hormones, because they are lipophilic substances of small size $(56,61)$. A placental transfer of $1,25-(\mathrm{OH})_{2} \mathrm{D}_{3}$ has been demonstrated in the cow and sheep $(49,62)$ and to a lesser extent also in the rhesus monkey (63), whereas conflicting results were obtained in rats $(59,64,65)$. Since the placental transfer of steroids probably depends more on their free than on their total concentrations (56), a marked species difference can occur from variation in DBP gradients between both compartments $(3,66)$. Until studies in man are available, our data can be interpreted either as an argument for direct placental transfer of $1,25-(\mathrm{OH})_{2} \mathrm{D}_{3}$ or for a regulation of the production of this hormone by one or more factors common to both compartments. Kinetic studies will be needed to solve the complex origin of $1,25-(\mathrm{OH})_{2} \mathrm{D}_{3}$ in the feto-maternal compartments.

The variation of $25-\mathrm{OHD}_{3}$ observed at the end of pregnancy probably represents differences in nutritional intake or skin-production of vitamin $\mathrm{D}$. The wide variation in total or free $1,25-(\mathrm{OH})_{2} \mathrm{D}_{3}$, however, (Fig. 4) warrants further study regarding its cause as well as its consequences for both the mothers and the neonates.

\section{ACKNOWLEDGMENTS}

We very much appreciated the technical expertise of $\mathrm{Mr}$. K. B. Tan, I. Jans, and E. Van Herck.

This work was supported by grants from the Belgian Queen Elisabeth Foundation, the Fonds Derde Cyclus K. U. Leuven (OT/V/44), and a grant from the Belgian National Foundation for Scientific Research to Dr. Bouillon.

\section{REFERENCES}

1. Refetoff, S. 1979. Thyroid hormone transport. In Endocrinology. L. J. De Groot, G. F. Cahill, L. Martini, D. H. Nelson, W. D. Odell, J. T. Potts, E. Steinberger, and A. I. Winegrad, editors. Grune \& Stratton, New York. 1: $347-356$.

2. West, C. D., and A. W. Meikle. 1979. Laboratory tests for the diagnosis of Cushing's syndrome and adrenal insufficiency and factors affecting those tests. In Endocrinology. L. J. De Groot, G. F. Cahill, L. Martini, D. H. Nelson, W. D. Odell, J. T. Potts, E. Steinberger, and A. I. Winegrad, editors. Grune \& Stratton, New York. 2: $1157-1177$.

3. Bouillon, R., H. Van Baelen, and P. De Moor. 1977. 
25-Hydroxyvitamin $\mathrm{D}$ and its binding protein in maternal and cord serum. J. Clin. Endocrinol. Metab. 45: 679-684.

4. Pike, J. W., S. Toverud, A. Boass, T. A. McCain, and M. R. Haussler. 1977. Circulating $1 \alpha, 25-(\mathrm{OH}) \mathrm{D}$ during physiological states of calcium stress. In Vitamin D: Biochemical Chemical and Clinical Aspects Related to Calcium Metabolism. A. W. Norman, K. Schaefer, J. W. Coburn, H. F. DeLuca, D. Fraser, H. G. Grigoleit, and D. von Herrath, editors. Walter de Gruyter \& Co., Berlin, Germany. 187-189.

5. Lund, B., and A. Selnes. 1979. Plasma 1,25-dihydroxyvitamin D levels in pregnancy and lactation. Acta Endocrinol. 92: 330-335.

6. Kumar, R., W. R. Cohen, P. Silva, and F. H. Epstein. 1979. Elevated 1,25-dihydroxyvitamin D plasma levels in normal human pregnancy and lactation. J. Clin. Invest. 63: $342-344$.

7. Steichen, J. J., R. C. Tsang, T. L. Gratton, A. Hamstra, and H. F. DeLuca. 1980. Vitamin D homeostasis in the perinatal period: 1,25-dihydroxyvitamin $\mathrm{D}$ in maternal, cord and neonatal blood. N. Engl. J. Med. 302: 315-319.

8. Brown, D. J., E. Spanos, and I. MacIntyre. 1980. Role of pituitary hormones in regulating renal vitamin $D$ metabolism in man. Br. Med. J. 1: 277-278.

9. Haddad, J. G., and J. Walgate. 1976. Radioimmunoassay of the binding protein for vitamin $\mathrm{D}$ and its metabolite in human serum: concentrations in normal subjects and in patients with disorders of mineral metabolism. J. Clin. Invest. 58: 1217-1222.

10. Bouillon, R., P. Van Kerckhove, and P. De Moor. 1976. Measurement of 25-hydroxyvitamin $\mathrm{D}_{3}$ in serum. Clin. Chem. 22: 364-368.

11. Bouillon, R., P. De Moor, E. G. Bagglioni, and M. R. Uskokovic. 1980. A radioimmunoassay for 1,25-dihydroxycholecalciferol. Clin. Chem. 26: 262-267.

12. Bouillon, R., H. Van Baelen, and P. De Moor. 1977. The measurement of the vitamin D-binding protein in human serum. J. Clin. Endocrinol. Metab. 45: 225-231.

13. Imawari, M., and D. S. Goodman. 1977. Immunological and immunoassay studies of the binding protein for vitamin $\mathrm{D}$ and its metabolites in human serum. J. Clin. Invest. 59: 432-442.

14. Haddad, J. G., and S. J. Birge. 1975. Widespread, specific binding of 25-hydroxycholecalciferol in rat tissues. J. Biol. Chem. 250: 299-303.

15. Kawakami, M., M. Imawari, and D. W. Goodman. 1979. Quantitative studies on the interaction of cholecalciferol (vitamin $\mathrm{D}_{3}$ ) and its metabolites with different genetic variants on the serum binding protein for these sterols. Biochem. J. 179: 413-423.

16. Bouillon, R., H. Van Baelen, and P. De Moor. 1980. Comparative study of the affinity of the serum vitamin D-binding protein. J. Steroid Biochem. 13: 1029-1034.

17. Lecureuil, M., G. Crouzat-Reynes, J. C. Besnard, and C. Choffel. 1978. Correlation of free thyroxine index and thyroxine: thyroxine-binding globulin ratio with the free thyroxine concentration as measured by the thyroxine and thyroxine-binding globulin radioimmunoassay. Clin. Chim. Acta 87: 373-381.

18. De Moor, P., K. Heirwegh, J. F. Heremans, and M. Declerk-Raskin. 1962. Protein binding of corticoids studied by gel filtration. J. Clin. Invest. 41: 816-827.

19. Tulchinsky, D., and I. J. Chopra. 1973. Competitive ligand-binding assay for measurement of sex hormonebinding globulin (SHBG). J. Clin. Endocrinol. Metab. 37: 873-881.

20. Rosenfield, R. L. 1975. Studies of the relation of plasma androgen levels to androgen action in women. J. Steroid Biochem. 6: 695-702.

21. Rosenfield, R. L. 1971. Plasma testosterone binding globulin and indexes of the concentration of unbound androgens in normal and hirsute subjects. J. Clin. Endocrinol. Metab. 32: 717-728.

22. Bouillon, R., and H. Van Baelen. 1979. The transport of vitamin D. In Vitamin D: Basic Research and Its Clinical Application. A. W. Norman, K. Schaefer, D. Von Herrath, H. G. Grigoleit, J. W. Coburn, H. F. DeLuca, E. B. Mawer, and T. Suda, editors. Walter de Gruyter \& Co. Berlin, Germany. 137-143.

23. Bouillon, R., P. Van Kerckhove, and P. De Moor. 1976 Characteristics of the vitamin D-binding proteins in different species. Calcif. Tissue Res. 21(Suppl.): 172-176.

24. Baumann, G., G. Rappaport, T. Lemarchand-Béraud, and J. P. Felber. 1975. Free cortisol index: a rapid and simple estimation of free cortisol in human plasma. J. Clin. Endocrinol. Metab. 40: 462-469.

25. Jasani, C., B. E. C. Nordin, D. A. Smith, and I. Swanson 1965. Spinal osteoporosis and the menopause. Proc. R. Soc. Med. 58: 441-444.

26. Gallagher, J. C., J. Aaron, A. Horsman, D. H. Marshall, R. Wilkinson, and B. E. C. Nordin. 1973. The crush fracture syndrome in postmenopausal women. Clin. Endocrinol. Metab. 2: 293-315.

27. Reeker, P. R., P. D. Saville, and R. P. Heaney. 1977 Effect of estrogens and calcium carbonate on bone loss in postmenopausal women. Ann. Intern. Med. 87: $649-655$.

28. Gallagher, J. C., B. L. Riggs, J. Eisman, A. Hamstra, S. B. Arnaud, and H. F. DeLuca. 1979. Intestinal calcium absorption and serum vitamin $\mathrm{D}$ metabolites in normal subjects and osteoporotic patients. Effect of age and dietary calcium. J. Clin. Invest. 64: 729-736.

29. Heaney, R. P., and T. G. Skillman. 1971. Calcium metabolism in normal human pregnancy. J. Clin. Endocrinol. Metab. 33: 661-669.

30. Riggs, B. L., J. Jowsey, R. S. Goldsmith, P. J. Kelly, D. L. Hoffman, and C. D. Arnaud. 1972. Short- and longterm effects of estrogen and synthetic anabolic hormone in postmenopausal osteoporosis. J. Clin. Invest. 51: 1659-1663.

31. Heaney R. P., R. R. Recker, and P. D. Saville. 1978. Menopausal changes in calcium balance performance. I. Lab. Clin. Med. 92: 953-963.

32. Eskildsen, P. C., B. Lund, O. H. Sørensen, B. Lund, J. E. Bishop, and A. W. Norman. 1979. Acromegaly and vitamin D metabolism: effect of bromocriptin treatment. J. Clin. Endocrinol. Metab. 49: 484-486.

33. Bell, N. H., P. H. Stern, E. Pantzer, T. K. Sinha, and H. F. DeLuca. 1979. Evidence that increased circulating $1 \alpha, 25$-dihydroxyvitamin $\mathrm{D}$ is the probable cause for abnormal calcium metabolism in sarcoidosis. J. Clin. Invest. 64: 218-225.

34. Haussler, M. R., D. J. Baylink, M. R. Hughes, P. F Brumbaugh, J. E. Wergedal, F. H. Shen, R. L. Nielsen, S. J. Counts, K. M. Bursac, and T. A. McCain. 1976. The assay of $1 \alpha, 25$-dihydroxyvitamin $\mathrm{D}_{3}$ : physiologic and pathologic modulation of circulating hormone levels. Clin. Endocrinol. 5: 151s-165s.

35. Gray, R. W., D. R. Wilz, A. E. Caldas, and J. Lemann Jr. 1977. The importance of phosphate in regulating plasma $1,25-(\mathrm{OH})_{2}$ vitamin $D$ levels in humans: studies in healthy subjects, in calcium-stone formers and in patients with primary hyperparathyroidism. J. Clin. Endocrinol. Metab. 45: 299-306.

36. Crilly, R. G., D. H. Marshall, A. Horsman, B. E. C. Nordin, 
and R. Bouillon. 1980. $1 \alpha$-Hydroxy $D_{3}$ with and without oestrogen in the treatment of osteoporosis. Proceedings of the Osteoporosis Meeting, Madison, Wisc. 8-12 June. In press.

37. Baski, S. N., and A. D. Kenny. 1977. Vitamin $\mathrm{D}_{3}$ metabolism in immature Japanese quail: effects of ovarian hormones. Endocrinology 101: 1216-1220.

38. Tanaka, Y., L. Castillo, M. J. Wineland, and H. F. DeLuca. 1978. Synergistic effect of progesterone, testosterone and estradiol in the stimulation of chick renal 25-hydroxyvitamin $D_{3}-1 \alpha$-hydroxylase. Endocrinology. 103: 20352039.

39. Spanos, E., D. I. Barrett, K. T. Chong, and I. MacIntyre. 1978. Effect of oestrogen and 1,25-dihydroxycholecalciferol on 25-hydroxycholecalciferol metabolism in primary chick kidney-cell cultures. Biochem. J. 174: 231-236.

40. Trechsel, U., J. P. Bonjour, and H. Fleisch. 1979. Regulation of the metabolism of 25-hydroxyvitamin $\mathrm{D}_{3}$ in primary cultures of chick kidney cells. J. Clin. Invest. 64: 206217.

41. Forfar, J. O. 1976. Normal and abnormal calcium, phosphorus and magnesium metabolism in the perinatal period. Clin. Endocrinol. Metab. 5: 123-149.

42. Tan, C. M., A. Raman, and T. A. Sinnathray. 1972. Serum ionized calcium levels during pregnancy. J. Obstet. Gynaecol. Br. Commonw. 79: 694-697.

43. Cushard, W. G., M. A. Crediton, J. M. Canterbury, and E. Reiss. 1972. Physiologic hyperparathyroidism in pregnancy. J. Clin. Endocrinol. Metab. 34: 767-771.

44. Bouillon, R., and P. De Moor. 1973. Pathophysiological data obtained with a radioimmunoassay for human parathyroid hormone. Ann. Endocrinol. 34: 657-667.

45. Manolagas, S. C., D. C. Anderson, and G. A. Lumb. 1979. Glucocorticoids regulate the concentration of 1,25dihydroxy-cholecalciferol receptors in bone. Nature (Lond.). 277: 314-315.

46. Shenolikar, I. S. 1970. Absorption of dietary calcium in pregnancy. Am. J. Clin. Nutr. 23: 63-67.

47. Williams, M. L., C. S. Rose, G. Morrow, S. E. Sloan, and L. A. Barners. 1970. Calcium and fat absorption in neonatal period. Am. J. Clin. Nutr. 23: 1322-1330.

48. Sutton, A., and D. Barltrop. 1973. Absorption, secretion and endogenous faecal excretion of calcium by the newborn infant. Nature (Lond.). 242: 265.

49. Care, A. D., R. Ross, D. W. Pickard, and J. S. Robinson. 1980. The intrauterine control of mineral metabolism. Calcif. Tissue Int. 31(Suppl.): 29A.

50. Rosen, J. F., M. Roginsky, G. Nathenson, and L. Finberg. 1974. 25-Hydroxyvitamin $\mathrm{D}$, plasma levels in mothers and their premature infants with neonatal hypocalcemia. Am. J. Dis. Child. 127: 220-223.

51. Hillman, L. S., and J. G. Haddad. 1974. Human perinatal vitamin $D$ metabolism. I. 25-Hydroxyvitamin $D$ in maternal and cord blood. J. Pediatr. 84: 742-749.
52. Dent, C. E., and M. M. Gupta. 1975. Plasma 25-hydroxyvitamin $D$ levels during pregnancy in Caucasians and in vegetarian and non-vegetarian Asians. Lancet. II: 10571060.

53. Reiter, E. O., G. D. Braunstein, A. Vargas, and A. W. Root 1979. Changes in 25-hydroxyvitamin $D$ and 24,25dihydroxyvitamin $\mathrm{D}$ during pregnancy. Am. J. Obstet. Gynecol. 135: 227-229.

54. Haddad, J. G., V. Boisseau, and L. V. Avioli. 1971. Placental transfer of vitamin $\mathrm{D}_{3}$ and 25-hydroxycholecalciferol in the rat. J. Lab. Clin. Med. 77: 908-915.

55. Hirschfeld, J., and O. Lunell. 1962. Serum protein synthesis in foetus: haptoglobins and group-specific components. Nature (Lond.). 196: 1220.

56. Josimovich, J. B. 1973. Passage of hormones through the placenta. In Handbook of Physiology. American Physiological Society, Washington D. C. 2: 277-284.

57. Lester, G. E., T. K. Gray, and R. S. Lorenc. 1978. Evidence for maternal and fetal differences in vitamin $D$ metabolism. Proc. Soc. Exp. Biol. Med. 159: 303-307.

58. Tanaka, Y., B. Halloran, H. K. Schnoes, and H. F. DeLuca. 1979. In vitro production of 1,25-dihydroxyvitamin $D_{3}$ by rat placental tissue. Proc. Natl. Acad. Sci. U. S. A. 76: 5033-5035.

59. Gray, T. K., G. E. Lester, and R. S. Lorenc. 1979. Evidence for extra-renal $1 \alpha$-hydroxylation of 25-hydroxyvitamin $\mathrm{D}_{3}$ in pregnancy. Science (Wash. D. C.). 204: 1311-1313.

60. Weisman, Y., A. Harell, S. Edelstein, M. David, Z. Spirer,

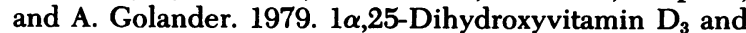
24,25-dihydroxyvitamin $D_{3}$ in vitro synthesis by human decidua and placenta. Nature (Lond.). 281: 317-319.

61. Fisher, D. A. 1979. Fetal endocrinology: endocrine disease and pregnancy. In Endocrinology. L. J. De Groot, G. F. Cahill, L., Martini, D. H. Nelson, W. D. Odell, J. T. Potts, E. Steinberger, and A. L. Winegrad, editors. Grune \& Stratton, New York. 3: 1649-1663.

62. Barlet, J. P., M. J. Davico, J. Lefaivre, and B. J. Carrillo. 1979. Fetal blood calcium response to maternal hypercalcemia induced in the cow by calcium infusion or solanum glaucophyllum ingestion. Horm. Metab. Res. 11: 57-60.

63. Tsang, C., J. Steichen, F. Greer, H. Schedewic, M. Ho, and J. Whitsett. 1980. Perinatal calcium and vitamin D metabolism. Calcif. Tissue Int. In press.

64. Weisman, Y., R. Sapir, A. Harell, and S. Edelstein. 1976 Perinatal metabolism of vitamin D in the rat. Pediatr. Res. 10: 416. (Abstr.)

65. Weisman, Y., A. Vargas, G. Duckett, E. Reiter, and A. W. Root. 1978. Synthesis of 1,25-dihydroxyvitamin D in the nephrotectomized pregnant rat. Endocrinology. 103: 1992-1996.

66. Bouillon, R., G. Vandoren, H. Van Baelen, and P. De Moor. 1978. Immunochemical measurement of the vitamin D-binding protein in rat serum. Endocrinology. 102: $1710-1715$. 